\title{
Suburbia as a Narrative Space in the Cinematic Universe of Douglas Sirk
}

\author{
Nieves Alberola Crespo \\ alberola@ang.uji.es \\ Universitat Jaume I, Spain \\ José Javier Juan Checa \\ josejc81@hotmail.com \\ Independent researcher
}

Alberola Crespo, N., \& Juan Checa, J.J. (2021). Suburbia as a Narrative Space in the Cinematic Universe of Douglas Sirk. Language Value, 14(1), 112-132. Universitat Jaume I ePress: Castelló, Spain. http://www.languagevalue.uji.es.

July 2021

DOI: 10.6035/languagev.5953

ISSN 1989-7103

\section{ABSTRACT}

Douglas Sirk, now fully recognized as an influential filmmaker, was considered a successful but uninteresting director in the 1950s. His melodramas were considered bland and subsequently ignored because they focused on female-centric concerns. In the following decades, he started to be considered as an auteur that not only had an impeccable and vibrant mise-en-scène, but also a unique ability to deliver movies that might seem superficial on a surface level but were able to sneak in some subtle and revolutionary criticism about American society. The aim of this paper is to analyse the most rebellious and subversive aspects of Sirk's classic All that Heaven Allows (1955) from a gender perspective and how Todd Haynes's tribute Far from Heaven (2002) added new challenges by touching upon thorny subjects that already existed in Sirk's time but were deemed taboo for mass audiences.

Keywords: suburbia; films; women; gender; melodrama. 


\section{INTRODUCTION}

Suburbia and its residents became a very common topic in advertising campaigns, fiction and movies since the end of the Second World War, when Veterans returned home and started a family in these residential areas. It is said that Levittown (New York) was the first planned community to be built between 1947 and 1951; it offered attractive houses that included modern appliances, green lawns and white picket fences at a reasonable price. In the blink of an eye, Levittown became the symbol of the American Dream because it allowed many families to be homeowners. On the other hand, due to Clause 25 of the standard lease agreement signed by the first residents, it also became the symbol of racial segregation since houses could not be used or occupied by African American families. Perhaps these may be some of the reasons why many film directors started to use different genres to offer a portrait of life in the suburbs. From the melodramas in the 1950s, past the horror movies from the 1970s and the magical adventure productions from the 1980s to the sharp and disillusioned dramas and satire from the 1990s and especially in this new millennium, movies about American suburbia are as varied as it gets.

One of the first directors who shared his personal vision of the suburbs was Douglas Sirk, a German stage and screen director who had to leave for Hollywood in 1937 and achieved his greatest commercial success in the 1950s with films like Magnificent Obsession (1954), All that Heaven Allows (1955), Written on the Wind (1956), A Time to Love and a Time to Die (1958) and Imitation of Life (1959). Despite being very successful at the box office, his melodramas were considered bland and were subsequently ignored by professional reviewers because they focused on female-centric issues.

In the following decades, thanks to the support of avant-garde filmmakers, critics began to rewatch his filmography and discovered an auteur that not only had an impeccable and vibrant mise-en-scène, but also a unique ability to deliver films that seem superficial on a surface level but were able to sneak in some subtle and revolutionary criticism about American society. Way ahead of his time and contemporary moviemakers, he focused on themes such as social justice, sexuality and gender issues. Sirk's legacy has been fully appreciated in the last decades and his technique of hiding social commentary under a patina of melodrama has influenced a motley crew of some of the best film 
auteurs: Jean-Luc Godard, David Lynch, John Waters, Wong Kar-wai, Pedro Almodóvar and Todd Haynes.

Douglas Sirk focused his attention on the American housewife in his 1955 hit movie All that Heaven Allows, released a few years before Betty Friedan was asked to interview her former Smith College classmates and before her controversial book The Femenine Mystique (1964), that tackles with "the problem that has no name", was published. On a mere surface level, Sirk's film is a romantic drama that features everything you expect from a 1950s movie about suburbia and the American Dream, i.e., men in fedora hats and women with cooking aprons, trimmed lawns, barbecue and house parties. However, the film managed to show some hints of rebellion as it focused on the emotional complexity of the female protagonist and the narrow and prejudiced worldview of her suburban social circle. In 2002, almost fifty years later, Todd Haynes, one of the most well-known current auteur directors in Hollywood, paid homage to Sirk's story and motifs in Far from Heaven, and he added another direction and delved deeper into other issues that were not present in Sirk's production.

Since cinema mirrors the changes that take place in society, in this paper we will share our analyses of the portraits of housewives in the 1950s in All that Heaven Allows (1955) and Far from Heaven (2002). Both movies adhere to different points of view on the issue of women in general and gender issues more concretely. It is important to take into account that both films were produced at different waves of the feminist movement. Douglas Sirk's All that Heaven Allows (1955) was shot before the all-important second wave of feminism started to spread throughout the civilized cultures. On the other hand, Todd Haynes's Far from Heaven (2002) came not only after decades of the beneficial second wave feminism, but also after the consolidation of the third wave of feminism from the 1990s (Rampton, 2015, p. 4). Furthermore, the latter film is also positioned between Judith Butler's Gender Trouble (1990) and Undoing Gender (2004), and echoes the changes in society throughout the decades in terms of gender in comparison to Sirk's masterpiece.

Through the selection of these two on the surface quite similar productions from different time periods, we will be able to trace Sirk's unique ability to deliver Hollywood fare that seemed superficial on a surface level and how he was able to sneak in some 
subtle and revolutionary criticism about American society. The director's legacy will also be compared to Haynes's tribute as it included new challenges and obstacles for the defiant American housewives of suburbia, by touching upon thorny subjects that already existed in Sirk's time but were deemed taboo for mass audiences -perhaps producers back then thought that the general public would not be ready or qualified to identify and understand that the personal sphere is politics too.

\section{DOUGLAS SIRK, AN INTELLECTUAL IN HOLLYWOOD}

Born in Germany to Danish parents, Douglas Sirk attended German universities and focused on Philosophy, Art History and Painting. He also oversaw theatre productions based on works written by William Shakespeare, Bertold Brecht or Sophocles. Afterwards, he was able to get an apprenticeship at the famous German UFA studios (Klinger, 1994, p. 8). Unfortunately, the rise of Nazism forced him to flee from Germany, since his wife was Jewish. After a few detours, he arrived in Hollywood where he started working for the big Hollywood studios like Warner Bros. or Columbia. It was his relationship with Universal though that led to his most important and successful movies and to his title: the king of melodrama. Despite the immense box office success, in 1959, after the release of his latest hit Imitation of Life, Sirk not only left Hollywood and returned to Germany, but he also retired completely from filmmaking. He was immediately forgotten by the movie industry and only a few remembered him as the master of kitsch (Kürten, 2008, p. 1).

It took a few decades until renowned auteur directors like Rainer Werner Fassbinder and other European directors of the Nouvelle Vague $e^{i i}$ started to highlight Sirk's merits and quality and a period of reevaluation started which led to his anointment as a "bonafide auteur by fully elaborating the relationship between form and content in his films" (Klinger, 1994, p. 10). His influence on many of the most prestigious directors of the last five decades assured him a position in film history.

All that Heaven Allows (1955), one of his finest masterpieces, is on a surface level, a melodrama about forbidden love, a love that transcends both social and societal rules. 


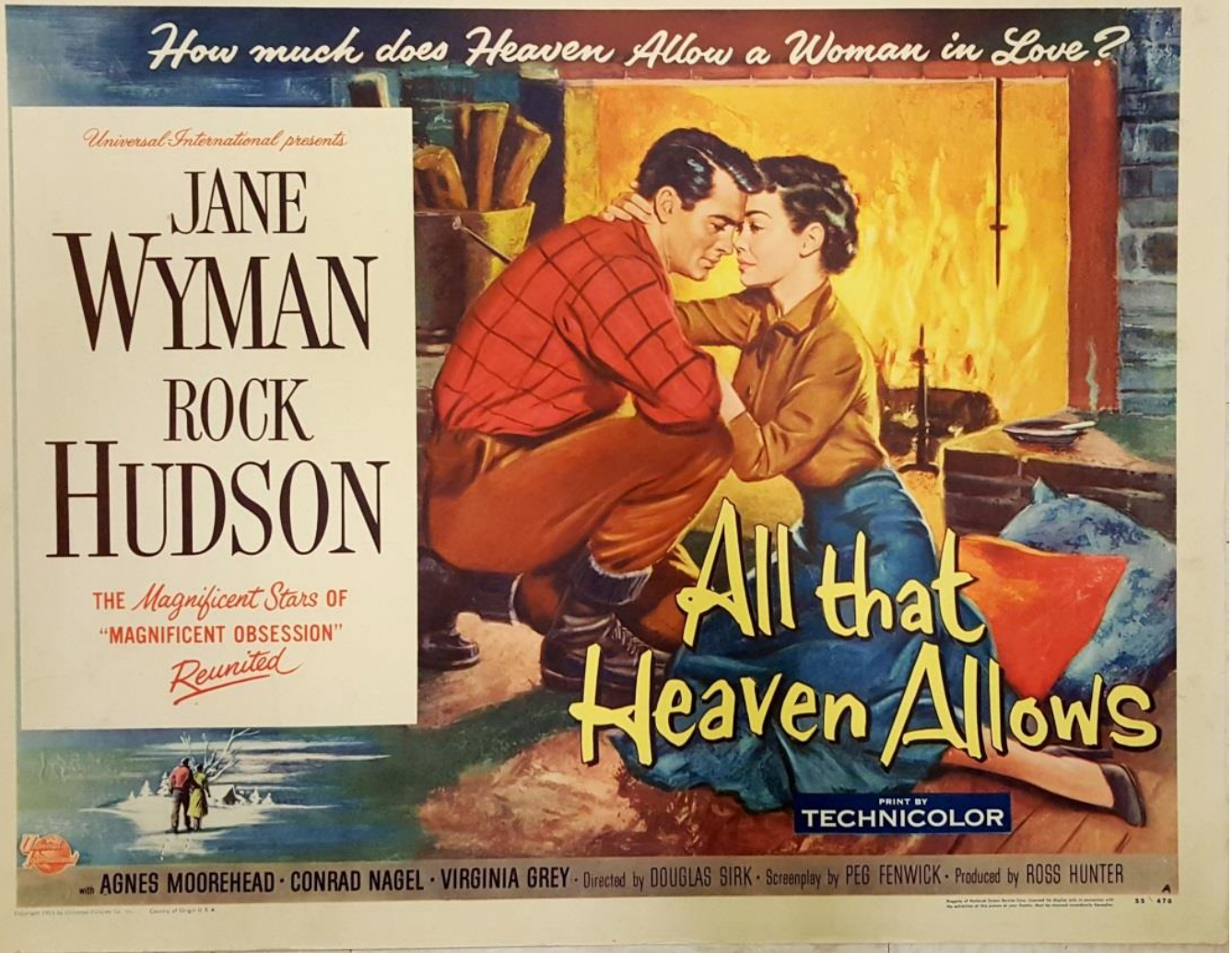

Figure 1. One of the original posters for All that Heaven Allows

But in Sirk's own words, it was also a story "about the contradiction between Henry David Thoreau's modified Rousseauismiii and real American society" (Campbell, 2008, p. 47). As an intellectual, that even attended Einstein classes on Relativity back in Germany, and also as an outsider, he was in the perfect position to film the contrast and clash between different American communities. On the one hand, the so-called Boomers, that were conservative and consumerist. On the other hand, the more free-spirited individuals who identified with the Romantic and Transcendentalist movement. Our heroine, Cary Scott, will have to make up her mind of becoming the typical American housewife that just stays at home, watching mind-numbing television while she is trying to be the perfect spouse.

The story follows Cary Scott, played by Jane Wyman, a wealthy widow who lives in the suburbs of Stoningham in New England. Her social life revolves around her friends from her club and her children who are of college age and visit her on weekends. Some men in her social circle woo her but she is not interested. She makes friends with Ron Kirby, her gardener, "an independent type" who leads a simple life in the country, far away from the materialistic society - played to full effect by 1950s heartthrob Rock Hudson. 
Ron, despite not having read Henry David Thoreau -author of Waldeniv and Civil Disobedience-, lives a free-spirited life out in the woods, "in a glasshouse" so that he can see the stars at night in the sky when he is in bed. Unconsciously, he is presented as adoptive child of the Enlightenment, a movement that started in France and that American romantic writers, such as Thoreau, drew inspiration from in order to develop their writings and concepts.

Ron will invite her to meet his friends, the Andersons, simple people who enjoy life far from the patterns of materialistic society. Mick Anderson was once a very important executive at an advertisement company in New York City. Mick thought that money and an important position would make him feel secure. But when he met Ron, who did not have either one and did not seem to need them, Mick was completely baffled and his life got turned upside down. Mick's bible is Walden, and the philosophy within this book is quoted in the movie:

The mass of men lead lives of quiet desperation. Why should we be in such desperate haste to succeed? If a man does not keep pace with his companions, perhaps it is because he hears a different drummer. Let him step to the music which he hears, however measured... or far away.

For the first time in her life, Cary is baffled and at the same time fascinated with this philosophy and outlook on life. Ron represents people who seem to have no need for wealth and status and he lives by "to thine own self be true", a quote taken from Act 1, Scene 3, and lines 78-82 from Hamlet written by William Shakespeare. A quote that an intellectual like Sirk just had to include in his movie. This quote refers to actual commitment and honesty, which is the opposite of life in suburbia, where characters like Howard and Mona act selfish- and cowardly.

The friendship and mutual feelings between them grow and Ron proposes to her. Cary accepts his proposal, but her friends and her children will not understand this change because they despise everything that is different or consider it socially unacceptable. Eventually, she gives in to the pressure and breaks off the engagement. When Cary's children announce that their life projects do not include their mother, she realizes that her sacrifice and commitment to her family were in vain. Encouraged by her doctor Dan Hennessy, she will take the step of going to talk to Ron as she has realized how wrong 
she was in allowing social conventions to dictate her life choices and she decides to ignore what everyone else thinks and instead just follows her heart.

Even though the plot may sound like a mawkish melodrama, the movie proves to be an intricately complex filmic experience. It is shot in vibrant Technicolor, where Cary and Howard, one of her suitors, wear opposing primary colours to visually hammer their differences home. It is also one of those movies where one of its motifs -human beings as part of nature- is signified by having a deer appear in the climax of the movie, when Cary and Ron finally get back together. The deer acts as a visual metaphor of nature approving of this union -and way of life- and giving the couple her blessing.

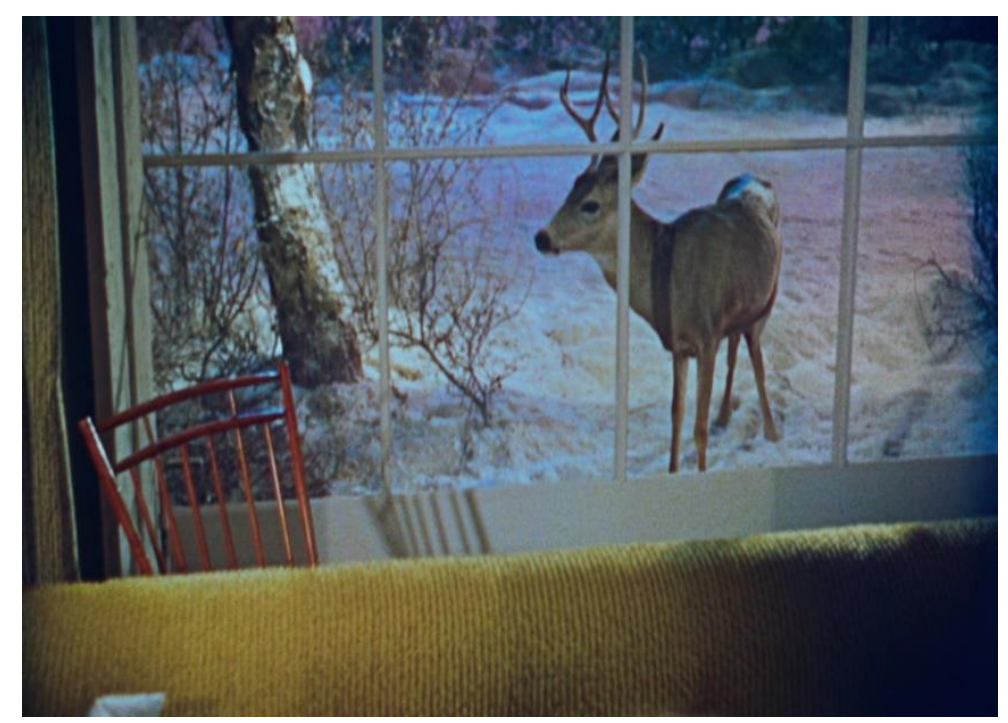

Figure 2. The appearance of the deer as a metaphor for nature's approval.

And yet, Sirk expertly dissects American suburban life from the 1950s with its upperclass conventions, faux formalities and conformity in a way that is closer to relevant authors like Herman Hesse ${ }^{v}$ than to mind-numbing soap operas. In fact, the German writer once said that "the bourgeois prefers comfort to pleasure, convenience to liberty and a pleasant temperature to the deathly inner consuming fire" (Hesse, 2021). Our heroine Cary has to choose between Walden and suburbia, while being under the scrutiny of what society expects of a middle-aged widow, living in upper-class suburb in the 1950s.

The reader needs to understand that this movie was written and shot in the middle of the 1950s, and from our point of view, it is perfectly acceptable to consider Douglas Sirk a precursor to second-wave feminism. Sometimes important ideas and concepts are 
floating around in the minds of society waiting for someone to transcribe them into words. Sirk, being a well-educated man of letters, transcribed that zeitgeist into moving images, while in the same decade Betty Friedan transcribed them into words. She started doing research on her seminal work The Feminine Mystique when she was asked to interview her former Smith College classmates in 1957. She found out that many of them were unhappy with their lives as suburban housewives, despite what public opinion and the advertising industry said about the role of women. This prompted her to begin research and write an essay in order to challenge a widely shared belief in the 1950s that "women's lives would be fulfilled if they chose marriage over a profession" (Friedan, 1963, p. 454). Despite living in material comfort and being married with children, suburban housewives were unsatisfied and they could not voice their feelings. In the same manner, Friedan was unable to get her research and article published, so she had to rework her article into a book and continue fighting until 1964, when she was finally able to find a publisher interested in her work.

Sirk, a sophisticated and well-read intellectual, managed to bring integrity and thoughtprovoking female-centric issues -what Friedan called "the problem that has no name" $(1963$, p. 63) - to a wider audience. As of today, only a few selected directors have been able to work within the studio system of the big Hollywood machinery and still release a studio product with the director's vision intact. The German film director managed to deliver a very successful hit movie that is not so much for female audiences, but instead it is a universally likeable masterpiece that acts as an invitation to identify with and understand women (Gorr, 2016, p. 1).

Unfortunately, critical reaction in the 1950s was not good: At best, his style and vision were considered banal, because of his focus on female-centric issues. At worst, his movies were even considered bad taste (Schiebel, 2017, p. 1). Contemporary reviewers judging a film wrongly and being highly ignorant about its themes are still common to this day, which means that Douglas Sirk is in the superb company of master filmmakers like Alfred Hitchcock (Vertigo, 1958), Frank Capra (It's a Wonderful Life, 1946), Ridley Scott (Blade Runner, 1982) or the more recent David Prior (The Empty Man, 2020). The common thread among all these directors is the fact that reviewers were not able to 
appreciate or even recognize the undercurrents and audiences did not care to engage with what these artistic versions offered.

Nowadays, one of Sirk's most celebrated scenes is the moment when Cary's kids give her a TV set as a Christmas present. In order to get the whole emotional impact behind that scene, one needs to explain the steps that lead up to it. She had already been told by her friend Sara that she "should get a TV set", although it was considered to be "the last refuge for lonely women" who watched the dramatic stories on TV as surrogate emotions, a sort of state of isolated seclusion. But Cary refused to accept that fate and when the TV salesman showed up, she got rid of him in humourful fashion. She chose real life, her authentic feelings for Ron, instead of the TV serials of that time. She did not want to fall again into the trappings of the 1950s ideal, because she was more concerned about her personal wants, needs and desires, not just as a woman, but as a human being (Gorr, 2016, p. 1).

Her honest and personal decision was met with prejudices and snarled by her inner circle. For example, Mona Plash will not only criticize what Cary wears but also that she dates a younger man who is a mere gardener, which is completely unfitting for a middleclass woman. She even goes so far as to spread rumours about Cary dating Ron while her husband was still alive.

In this vein, one of the cruellest moments is when Cary tells her kids, Kay and Ned, about Ron's wedding proposal. She wants them to give Ron a fair shake, but from the very start of the conversation, both of them refuse to give him a chance. And every explanation on Ron's part is met with derision and flat-out rejection.

Ned: $\quad$ But this has been the family house for I don't know how long. This is the place
we were born!
Kay: $\quad$ You don't know Mother as we know her. She's really much more conventional
than you seem to think she is. She has the innate desire for group approval,
which most women have.

Ned: $\quad$ Never mind the $\$ 10$ words. And where, if I may ask, do you expect our mother... and, I suppose, us too to live? 
As we can see, the kids reply with selfish reasons and even go as far as to give a psychological explanation about their mother's personality. The psychological aspect was already mentioned at the beginning of the movie, when Kay gives a lecture about Egyptian traditions to her mother. In that ancient society, spouses were considered just another material possession of the husband and when the man died, it was expected that the wife accompanied him on his last travel... which means the wife was buried alive alongside her partner. Kay, for all her university knowledge, is unable to realize that her mother's experience is a source of wisdom. Kay does not understand the metaphor behind her own lecture. She sees it as something that happened millenniums ago; she fails to see that there are more ways to be imprisoned and buried alive than only the literal meaning.
Kay: $\quad$ Personally, I never subscribed to that old Egyptian custom. At least I think it was Egypt.
Cary: What Egyptian custom?
Kay: $\quad$ Of walling up the widow alive in the funeral chamber of her dead husband along with his other possessions. The theory being that she was a possession too. She was supposed to journey into death with him. The community saw to it. Of course, that doesn't happen anymore.
Cary: $\quad$ Doesn't it? Well, perhaps not in Egypt.
Kay: What do you mean?
Cary: $\quad$ Oh, nothing. Let's go downstairs.

It is ironic that Kay with all her theory and her supposed smarts is unable to realize that her piece of trivia is not that far away from ancient Egypt and more important, not that far away from her own mother. To make Cary's fate even crueller, both kids backpedal as soon as they had plans on their own -plans that they will not reveal until Christmas Eve.

\footnotetext{
Kay: $\quad$ Remember the afternoon that Freddie and I had the big fight? That's when we found out we loved each other. Mama, he's so wonderful.

Cary: $\quad$ Yes, I remember. That was the day you told me your life would be ruined if I married Ron.
} 
Kay: I was being childish. You shouldn't have let me get away with it. Of course, that was different. You didn't really love him, did you?

$[\ldots]$

Ned: Hey, this is Christmas. Let's enjoy it. After all, it'll probably be the last one we spend in this house.

Cary: What do you mean?

Ned: Kay's getting married. And if I'm not called up right away, I'm in line for the Walker Scholarship which means a year in Paris. After that, onto Iran with the Dayton Company. I didn't want to tell you till I had it pretty well cinched. [...] Yes, with Kay and I away, I think we should sell the house.

Cary: The house?

Ned: $\quad$ It's too big for one person. What with taxes...

After their appeal to Cary's emotions -ironically without taking into consideration their mother's emotions-, and after mentioning several times how Egyptians kept people alive behind walls, brother and sister were happy enough to leave their mother behind in this suburban "prison", all alone with a TV set that ironically preached "Drama, comedy, life's parade at your fingertips".

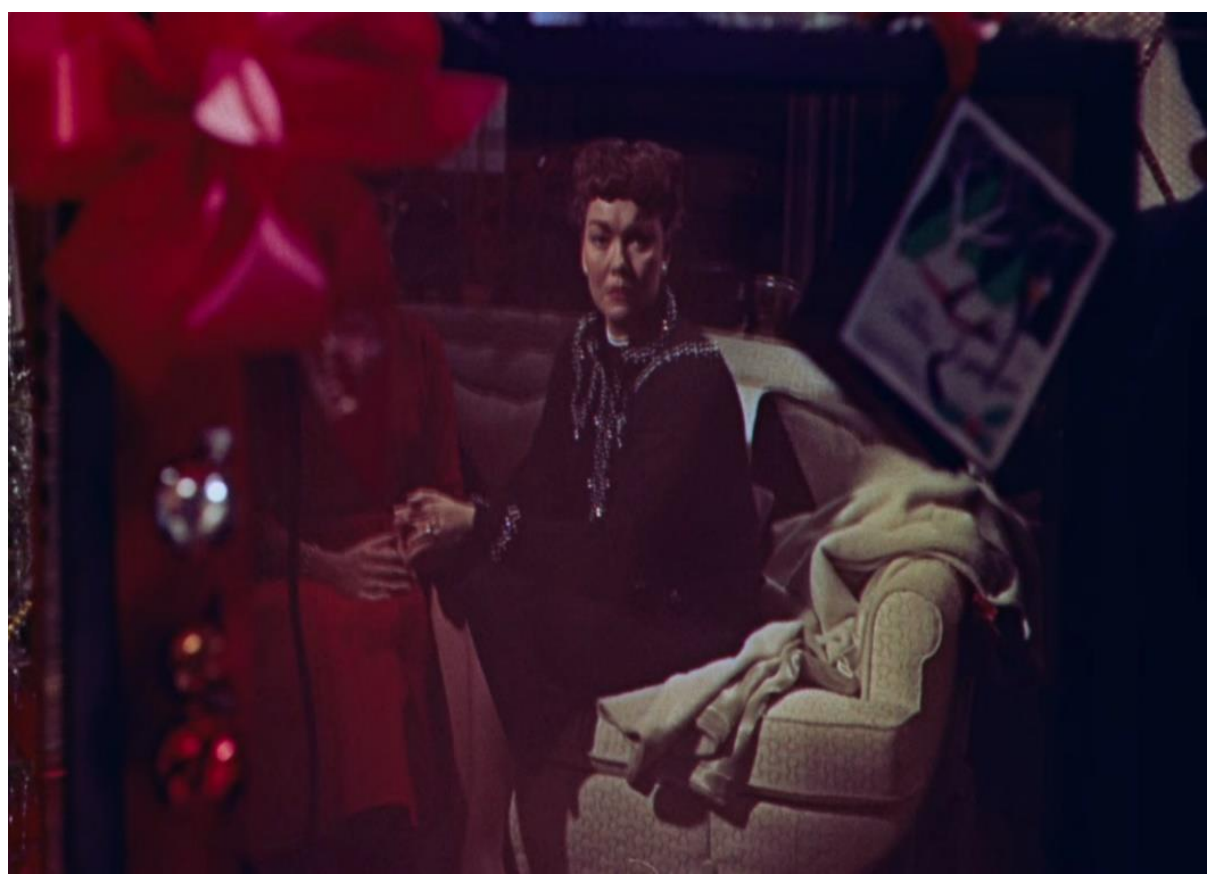

Figure 3. The iconic framing of Cary's prison.

Especially Cary's son is totally unaware of his hypocrisy. A few months earlier, he was so hung up on the emotional question of accommodation, and now, when his future is 
already laid out before him, he talks about selling the house where he grew up for petty tax reasons.

Only Kay has a moment of epiphany, when she realizes that their vain objections have been an obstacle for their mother's happiness.

Kay: $\quad$ Mama? Mama!
Cary: $\quad$ Don't you see, Kay? The whole thing's been so pointless.
Kay: $\quad$ Oh, mama, I'm... I'm terribly sorry. I didn't mean to hurt you.

Cary's response "Don't you see, Kay? The whole thing's been so pointless" is as bitter as tragic because all her sacrifices were in vain. She gave up on her inner feelings and desires for her family and she was tossed aside at the next best opportunity. Her profoundly sad reply only acts as a wake-up call for her daughter -maybe for prophylactic reasons as this situation could very well happen to her too-, while her son is still oblivious and as uncaring as a capitalistic mind can get, towards his mother's loneliness. The metaphor of Cary's face reflecting on the TV screen ${ }^{\mathrm{vi}}$ is haunting, because it is a visual representation of her entrapment in the confinements of her suburban life. Another interesting aspect of All that Heaven Allows is the way kisses and passion are handled. Movies usually had this "taming of the shrew" approach, when it came to kisses, which meant, that for dramatic or even comedic effect, women were angry or in the middle of doing something else, when, all of a sudden, the man comes around, grabs her by the shoulders and just kisses her. Women's emotions were second to the male passion.

Amongst the male characters of the movie, the character of Howard Hoffer, a supposedly educated and nice-mannered successful husband, is deconstructed by the director. One expects that Ron, being a gardener, would be less polite and wellmannered than Ron, but Howard is a wolf in sheep's clothing. He is a womanizer that is unfaithful to his wife and tries to forcefully kiss Cary and makes indecent, dishonest proposals about getting together in New York while his wife stays at home with their children. In Mona's words: "We do not know if she (Howard's wife) is a saint or just not very bright". 
On the other hand, every kiss by both Cary and even her daughter Kay with their partners (Ron and Freddie) take place on women's terms (Gorr, 2016, p. 1). One scene in particular stands out: Kay's boyfriend wants to kiss her, but she misreads him and starts going on about psychology. Most films -even today- would have used that scene for a comedic effect by the male partner just interrupting her with a kiss, but her boyfriend waits patiently and even hands out a halfway acceptable compliment: "How can anyone so little, be so smart, and yet so pretty?".

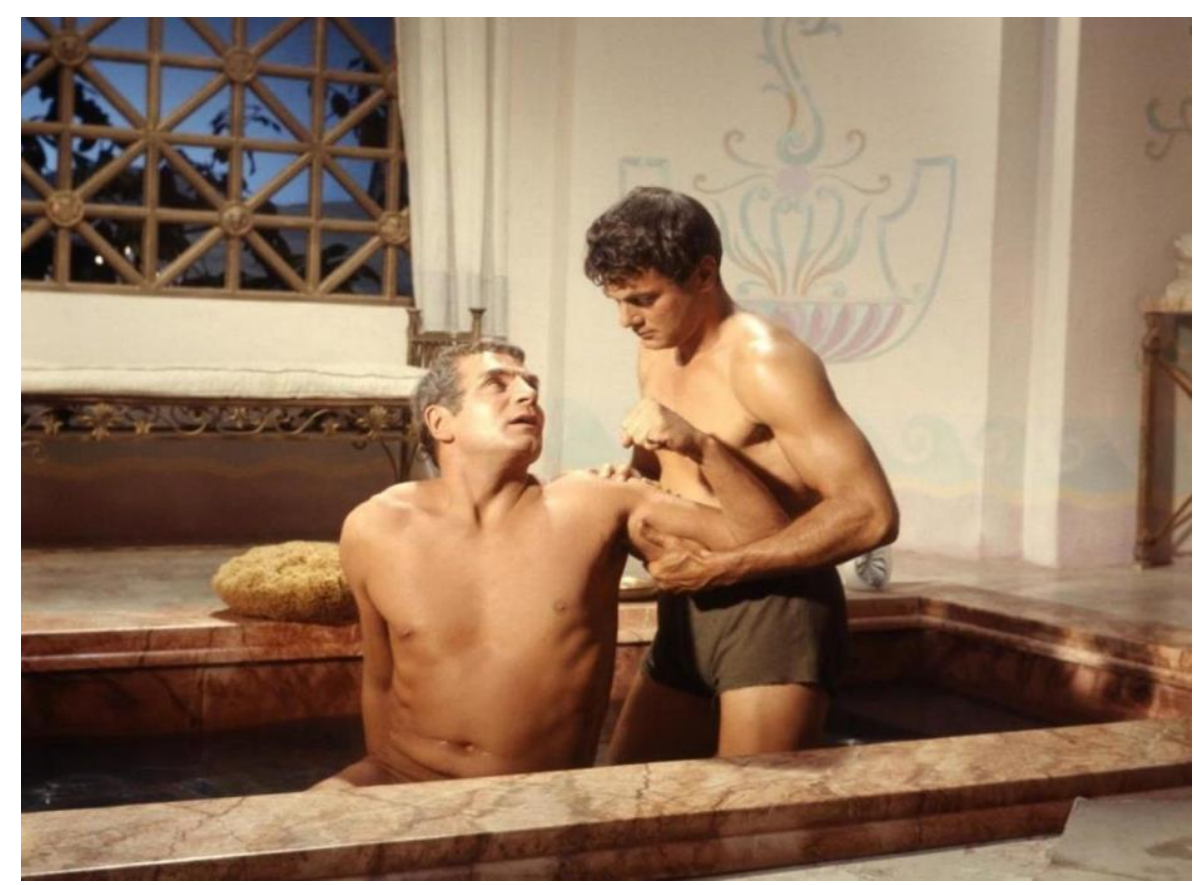

Figure 4. One of the cut scenes of Stanly Kubric's Spartacus.

Once again, we should be reminded of the fact that this is not a 2021 film by Greta Gerwig, but a studio movie from the 1950s. There is a level of subversion here at work, that huge movies from later decades (e.g., Spartacus (1960) by Stanley Kubrick, Ben-Hur (1959) by William Wyler or Lawrence of Arabia (1962) by David Lean) were not allowed to pull off. For example, any insinuation of homosexuality was cut out of Kubrick's epic, because producers thought that any mention of taboo themes would be controversial and distasteful for audiences.

\section{DOUGLASS SIRK'S LEGACY: “ONE ART” BIGGER THAN LIFE}

Working in Hollywood has always been extremely tough, because the only colour of Hollywood that matters is green, the colour of money, which means that artistic integrity 
is second to commercial success. Especially foreigners, used to more artistic liberties in their homeland, get crushed by the Hollywood machinery. Only a few movie directors are able to deliver a commercial product with an artistic vision behind it. Douglas Sirk is one of them, his films were only commercial on the surface, but beneath there were overtones of subversion and intellect. Sirk retired but in the 1970s many avant-garde directors started to discover and appreciate Sirk's mise-en-scène.

Working since the 1980s, Todd Haynes filmography focuses on imaginary societies, popular musicians and gender roles with a special focus on homosexual themes which makes him the poster child for the New Queer Cinema movement (Rich, 2004, p. 53). These types of queer-themed films focus on "revised issues of minority representations and sexual subjectivity" (Rich, 1992, p. 1).

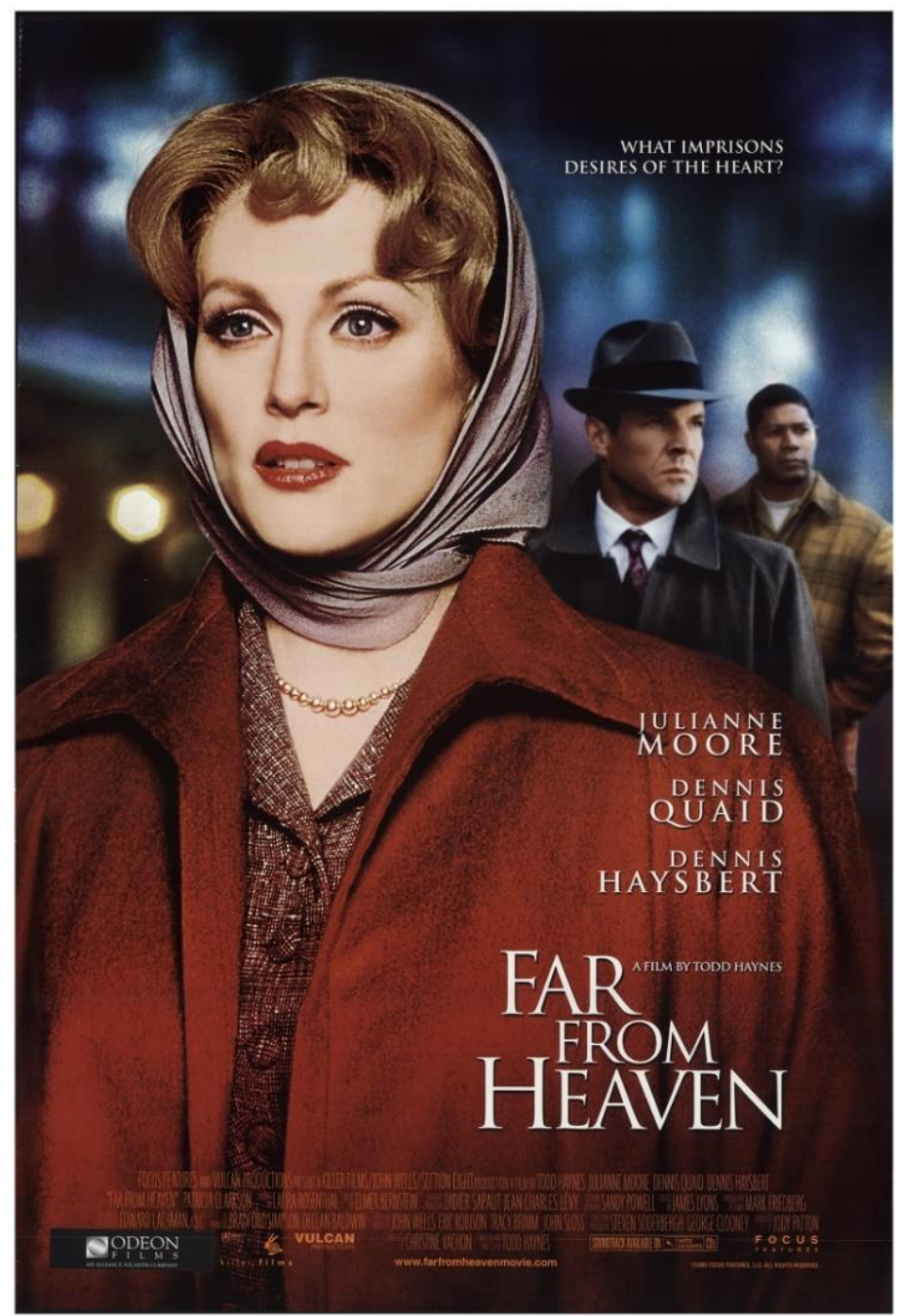

Figure 5. Far from Heaven's original poster.

Almost five decades after Sirk's movie, Todd Haynes had the chance to be more subversive vii in his homage called Far from Heaven (2002), which follows loosely the plot, 
themes and directorial style from Sirk's classic. Opposite to what happened to All that Heaven Allows, Haynes's movie was well received by critics, because it touched upon hot button topics like homosexuality and racism. With a hint of Martin Luther Kings' "Loving Your Enemies" sermon from 1957 -the same year the movie is set-, the film criticizes not only the hidden racial prejudice in the North, but also the racism amongst the black community that refused to mix with whites and punished black people that did so. Homosexuality in the 1950 s is the other add-on in this story, as it shows how society mistreated and isolated them and even went as far as using conversion therapy on them. These themes turned Far from Heaven into the director's breakthrough and recognition as an auteur voice and earned him and the movie 4 nominations -but zero wins.

In 1957, Cathy Whitaker is the perfect suburban wife and mother. She is married to Frank, who is a successful advertiser. Her idyllic world cracks when her husband is detained by the police after getting caught cruising gay bars. He swears that it is all just a big mistake. However, Frank very often stays late at the office. One night, Cathy decides to bring him dinner and she walks in on him vehemently kissing another man. Frank confesses that he has "problems" and agrees to sign up for conversion therapy. To make things worse, this therapy stifles Frank's creativity at work and out of frustration due to his situation, he starts drinking. The peculiar combination of therapy, repressed sexual identity and alcohol turns Frank unable to get aroused with his wife and when she tries to console him, he just strikes her across the face.

All these events put their picture-perfect simulacrum of marriage to the test, and it only gets worse when Cathy starts to feel attracted to the African American Raymond Deagan, the son of Cathy's former gardener. They start to hang out more and more often together and their colour-blind friendship starts to grow. One time they are seen together by one of Cathy's neighbours -perhaps intentionally called Mona, like the gossipmonger from Sirk's classic- and the gossip spreads like wildfire. During a ballet performance by her young daughter, other mothers prevent their daughters from socializing with Cathy's family and Frank starts to get even angrier because of the rumours and other people marginalizing him. 


\begin{abstract}
Frank: Is it true, what they've been saying? [...] Because if it is, even in the slightest, I swear to God, Cathleen...

Cathy: $\quad$ Frank, I am sorry you even had to hear such nonsense.

Frank: $\quad$ Yeah, well, Dick Dawson didn't seem to think it was such nonsense when he snuck away from his desk to phone me today. Good heavens. He says the whole friggin' town's talking! [...] Christ, Cathleen, do you even have the slightest idea about what this could mean? Don't you realize the effect it's gonna have on me and the reputation I have spent the past eight years trying to build for you and the children and for the company?

Cathy: $\quad$ Frank, I swear to you, whatever Mona Lauder saw or thought she saw was entirely a figment of that woman's hateful imagination. Yes. I have spoken to Raymond Deagan on occasion. [...] But, apparently, even here in Hartford, the idea of a white woman even speaking to a colored man...

Frank: $\quad$ Oh, please! Just save me the Negro rights!
\end{abstract}

Cathy tries to put out all the fires by telling Raymond that they can't be friends anymore. The family takes a vacation to take their minds off of things, but Frank, inevitably, will fall into temptation once again when he meets a young man at the hotel in Miami -a well-known gay-friendly town for decades. In the meantime, the Deagan family also suffers the ire of their black and white neighbourhoods. Raymond's daughter gets assaulted by white boys and the African American community started throwing rocks at Deagan's windows. This harkens back to what Martin Luther King said about loving your enemies, and the problem of the black community not accepting African Americans mixing with whites.

After their vacation, Frank wants to get divorced because he wants to live with another man and Cathy wants to be together with Raymond, now that she is single again. But the Deagan family needs to move away and forget all their problems, because they are accepted by neither the black nor the white community. In the end, Cathy goes to the train station to say silently goodbye to Raymond and the movie ends ambiguously with Cathy's future being uncertain but wide open in front of her.

Stylistically, the movie follows very close Sirk's techniques. Haynes's copies Sirk's expressionistic use of colour in order to distance the three main characters from each other. Similar to All that Heaven Allows, we have one scene where the heroine wears 
the opposite colour of her male partner, but in this case, the male in the scene is her husband. The mirror in the scene acts as a further estrangement device.

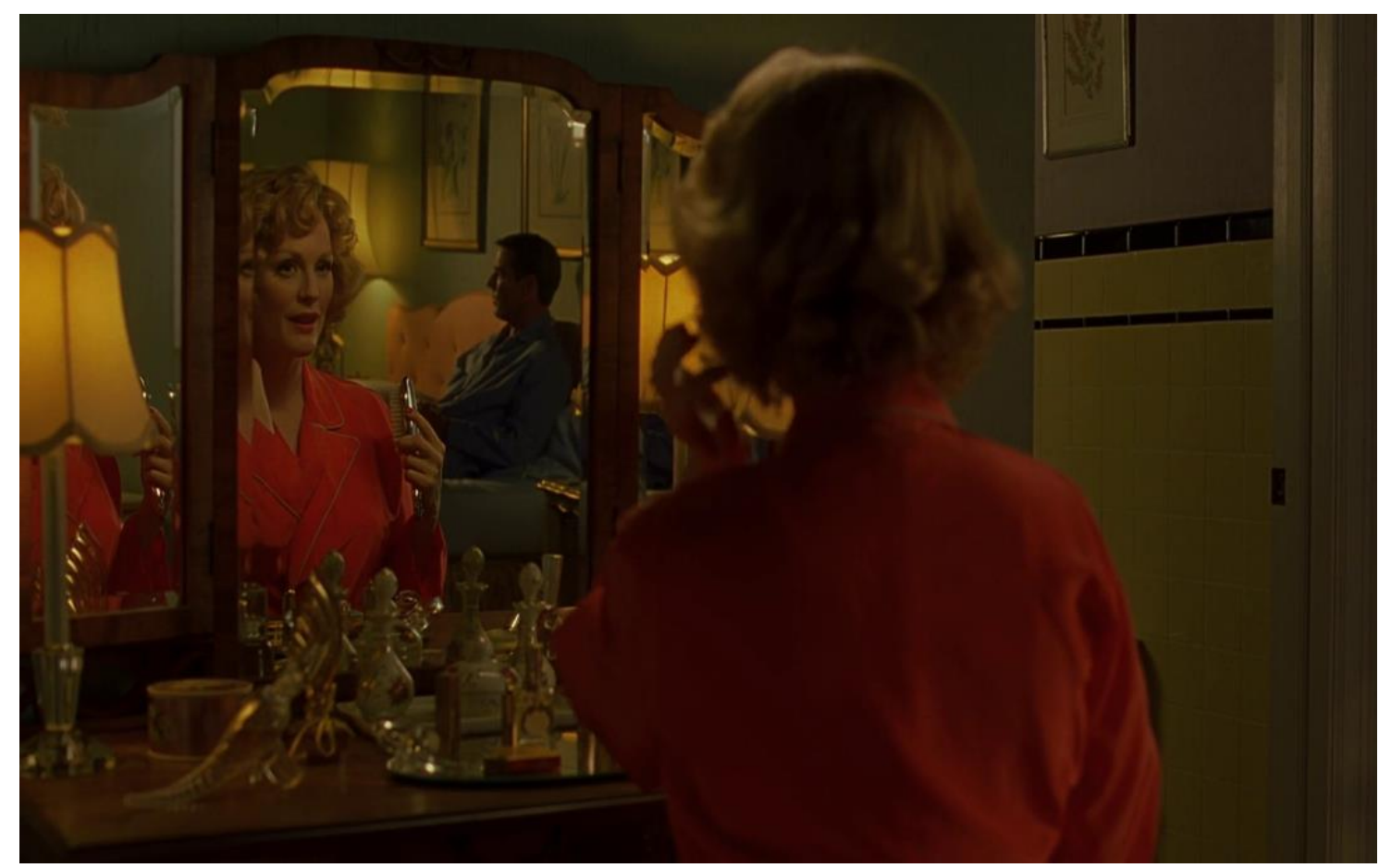

Figure 6. Clever use of colour and objects to emphasize estrangement.

Haynes's movie shares some similarities on a narrative level with Sirk's masterpiece, but Haynes's protagonist Cathy has more similarities with Kay, the daughter of Cary in All that Heaven Allows. Where Cary was genuinely a smart and intuitive woman with intellectual aspirations, her daughter was book smart with no life experience and worst of all, no ability to see that she was falling into the same trap as other housewives in the 1950s when she accepts the marriage proposal. In this sense, Cathy, as the alter ego of Kay, feels compelled to educate and train her daughter to become a supportive wife and dedicated mother, a role that is gender-based and defined by the men in her life and which she willingly, despite all her college education, passes along like an unwanted inheritance.

Haynes does not deconstruct the traditional female role but instead adds more contemporary controversial issues. He comes from a postmodernist background, where parody and kitsch are more prevalent. Haynes's movie was released after the publication of Judith Butler's book Gender Trouble (1990) and only two years before Undoing Gender (2004), both seminal books on gender and queer theory. Butler's influence is apparent, and Haynes uses Sirk's techniques to further his political agenda. 
His New Queer Cinema uses stylistical devices from classical Hollywood and delivers pastiche or even parodies of those movies in order to directly address a non-straight audience (Doty, 1998, p. 148).

Contrary to Sirk's happy ending, all three main characters are trapped by society in Haynes's film. Cathy (the housewife), Frank (the closet homosexual) and Raymond (the African American) are trapped in their bodies, minds and houses. They "are dependent upon their social environments, no matter how oppressive they are, for their sense of identification" (Richardson, 2006, p. 6). In Sirk's movie, the heroine finds her way; in Haynes's movie she accepts her fate, but does not understand, and seems to be a potential nuisance to her gay husband and to her African American gardener/potential lover. Is the director trying to position the female role closer to what Rosa Maria Rodriguez Magda refers to in her controversial book La mujer molesta (2019), where she describes how the more recent feminist movement needs to avoid the pitfalls of regressionism?

Cathy, Raymond and Frank are forced to accept the limitations imposed on women, gay people, and people of colour, that will not necessarily be on equal terms, because it should not be forgotten that there are contradictions and hierarchies even in the ways people are oppressed.

\section{CONCLUSION}

Hollywood productions reflect the times they were shot and, thus, movies act as time capsules that reflect the society of its time. Douglas Sirk managed to survive Hollywood and kept his artistic integrity intact. His films reflected the sociocultural climate of the 1950s and anticipated what was to come in the following years. By tapping into the zeitgeist of his decade, he managed to become a precursor of some of the tenets supported by the second-wave main feminist leaders.

The German director's legacy would allow following filmmakers to define their own visions of suburban society and share their own perspective on this topic. One of the directors influenced by his artistry has been Todd Haynes, whose production Far from Heaven shares more than one similarity with Sirk's All that Heaven Allows. Haynes's film 
maybe considered more of a product of theory of pluralism that focuses on inequality between groups and queer theory. It is also a millennium revision of the mid-century melodrama in which the unspoken could finally be spoken, but at the cost of a happy ending.

Cary, Douglas Sirk's heroine, was not a brilliant and rebellious student turned housewife like Cathy's character, but her internal turmoil drives the action and sets a precedent of subversion of traditional patterns. Her motivations in synthesis with Sirk's mise-en-scène created a fantasy where one could flee from social pressures. On the other hand, Far from Heaven -as the title fittingly suggests- offers a real portrait of life in the suburbs. Cathy is not prejudiced, believes in equal rights for the African Americans and supports the NACCP. Although she does not understand the intricacies of a homosexual identity in a repressed society, she will take interest in yet another civic cause. Likewise, she is considered a rather dangerous pro-integration type. Unfortunately, she will not be able to commune with neither of her civic fancies. She will stop being the prominent face of Hartford's Weekly Gazette, planning parties or posing at her husband's side on the advertisements. Without savings and without a job she will have to learn to master the art of losing, because true catharsis is unattainable in suburbia -an enchanting, "ever shining place, just beyond the fall of grace". 


\section{Notes}

i. This book argues that gender is a kind of an improvised performance and its publication influenced feminism, women's studies, and lesbian and gay studies. Butler's ideas about gender came to be considered as foundational to queer theory.

ii. A French art film movement that emerged in the late 1950s. It rejected traditional filmmaking conventions in favour of experimentation and a spirit of iconoclasm.

iii. Thoreau's works were influenced by French philosopher Jean-Jacques Rousseau, who played an important role in the spread of the Enlightenment ideals throughout Europe and the development of modern political, economic and educational thought.

iv. The text is a reflection upon simple living in natural surroundings. The work is a personal declaration of independence, social experiment, voyage of spiritual discovery, satire, and -to some degree- a manual for self-reliance.

v. The Swiss novelist explored in his works the individual's search for authenticity, self-knowledge and spirituality. His most well-known novel is Steppenwolf (1927).

vi. Thanks to metaphors, mirrors and light, Sirk performs constant transgressive exercises in his productions. Regarding the use of mirrors, Jesús González Requena states that it is Douglas Sirk "who, by populating the space with mirrors, announces with great finesse the dissolution of the classical canon. The mannerist plenitude of the cinematic universe of Sirk lies in the apparent invisibility of its deconstructive statements" (1987, p. 47). Translation made by the authors themselves.

vii. According to Juan Miguel Company, "Haynes's film allows us to witness the destruction of a bourgeois imaginary through an iconography born in the framework of the origins of consumer society" (2003, p. 118). Translation made by the authors themselves.

\section{REFERENCES}

Butler, J. (2003). Gender Trouble. Routledge.

Butler, J. (2004). Undoing Gender. Psychology Press.

Campbell, D. (2008). Walden in the Suburbs: Thoreau, Rock Hudson, and Natural Style in Douglas Sirk's All that Heaven Allows. In A.D. Hughes \& M. J. Hughes, Modern and Postmodern Cutting Edge Films (pp. 29-49). Cambridge Scholars Publishing.

Company, J. M. (2003). Persistance de la memoria. Reescribiendo una poética (Douglas

Sirk, 1955 / Todd Haynes, 2002). Litoral, (236), 114-120. Retrieved July 20, 2021, from http://www.jstor.org/stable/43402005

Doty, A. (1998). Queer Theory. In J. Hill \& P. Church Gibson (Eds.): The Oxford Guide to Film Studies (pp. 148-152). Oxford University Press.

Friedan, B. (1963). The Femenine Mystique. Penguin Classics.

González Requena, J. (1986). La metáfora del espejo. El cine de Douglas Sirk. Hiperión. 
Gorr, S. (2016). Feminism in a Feminine Space. Retrieved April 29, 2021, from http://www.thecinessential.com/all-that-heaven-allows-feminism

Hermann Hesse Quotes. (n.d.). Britannica.com. Retrieved July 19, 2021, from Britannica.com Web site:

https://www.britannica.com/quotes/biography/Hermann-Hesse

Klinger, B. (1994). Melodrama and Meaning: History, Culture, and the Films of Douglas Sirk. Indiana University Press.

Kürten, J. (2008). Douglas Sirk: Meister des Melodramas. Retrieved April 29, 2021, from https://www.dw.com/de/douglas-sirk-meister-des-melodramas/a-3536695

Rampton, M. (2015). Four waves of feminism. Pacific University, Oregon.

Rich, B. R. (1992). New Queer Cinema. Sight and Sound, 2(5), 30-35.

Rich, B. R. (2004). The New Queer Cinema. In S.G. Harry Benshoff (Ed.), Queer Cinema, The Film Reader (pp. 53-60). Routledge.

Richardson, N. (2006). Poison in the Sirkian System: The Political Agenda of Todd Haynes's Far from Heaven. Scope: An Online Journal of Film Studies, 6, 1-17.

Rodríguez Magda, R. M. (2019). La mujer molesta. Feminismos postgénero y transidentidad sexual. Ménades Editorial.

Scheibel, W. (2017). Revisiting Douglas Sirk's A Time to Love and a Time to Die. Retrieved April 29, 2021, from https://blog.oup.com/2017/04/douglas-sirk-a-time-to-loveand-a-time-to-die/

Received: 6 May 2021

Accepted: 26 July 2021 